\title{
SCIENTIFIC APPROACH OF 2013 CURRICULUM: TEACHERS' IMPLEMENTATION IN ENGLISH LANGUAGE TEACHING
}

\author{
Sri Ratnaningsih \\ Department of English, Indonesia University of Education, Indonesia \\ E-mail: chi.azure.chelsea@gmail.com
}

\begin{abstract}
APA Citation: Ratnaningsih, S. (2017). Scientific approach of 2013 curriculum: Teachers' implementation in English language teaching. English Review: Journal of English Education, 6(1), 33-40. DOI: 10.25134/erjee.v6i1.768.
\end{abstract}

\begin{abstract}
The research is aimed at investigating the teachers' implementation of scientific approach in English Language Teaching in one state junior high school in Bandung Regency. In addition, this research discusses the conformation of the Scientific Approach implementation and the lesson plans based on the 2013 curriculum. This research employs a case study qualitative research design. The data were obtained from classroom observation and teachers' lesson plan analysis and interview. The findings showed that the teachers implemented the scientific stages in English Language Teaching. They conducted observing, questioning, experimenting, associating and communicating in the sequence activities. Besides, the teachers can demonstrate the student-centered learning strengthened by collaborative, cooperative, active and meaningful learning. However, concerning the conformation of the implementation with lesson plans, based on the indicators, learning objectives, learning materials, learning media, scientific stages and Scientific Approach model (discovery learning, inquiry leaning, problem based learning and project based learning), the teachers still have to underline and mention the Scientific Approach model and state learning objectives. Furthermore, the other components have been presented well in both teaching and lesson plans.
\end{abstract}

Keywords: English language teaching, lesson plan, scientific approach, teaching practice, the 2013 curriculum

\section{INTRODUCTION}

Curriculum is defined as a plan for learning containing many kinds of learning instructions and outcomes (see Taba, 1962; Ruhimat et al., 2009, p.4). It includes the sequence activities that give something for the students to learn and experience through developing abilities to achieve specific educational goals and evaluation in the form of a written document (see Government Regulation Number 19 Year 2005 on National Education Standards; Kunandar, 2011, p.124; Hasanah, 2015; Olivia, 1988; Harold, 1965; Print, 1993).

In Indonesia's curriculum, English becomes a compulsory subject with a very important existence. The curriculum of English has experienced changes to acquire better student results in learning English
(Emilia, 2005). The English curriculum in Indonesia has witnessed at least eleven times of curricular changes - the 1945 curriculum, to 2006 curriculum (Alwasilah, 2012) as cited in (Hamied \& Musthafa, 2016) and the 2013 curriculum (KURTILAS) which uses Scientific Approach (Abidin, 2014; Hosnan, 2014; Yani, 2014; government's file).

The 2013 curriculum is implemented as one of government's efforts to answer the challenges of the advancing technology and rapid globalization. It is also related to the $21^{\text {th }}$ century characteristics. Morocco et al. (2008, p.5; see Abidin, 2014) argue that the $21^{\text {th }}$ century characteristics cover the ability of the highest understanding, critical thinking, collaboration and communication. Thrilling and Fadel $(2009$, p. 47$)$ add that $21^{\text {th }}$ century 
skills include: (1) life and career skills, (2) learning and innovation skills and (3) information, media, and technology skills. They underline that learning and innovation skills which connect to creative thinking, problem solving, communication, collaboration, creativity and innovation are the main skill to be improved.

The 2013 curriculum is hoped to realize the development of students' potential to create Indonesian citizens who are productive, creative, innovative, skillful, competitive, collaborative and independent through the integrated attitudes (students know "why"), skills (students know "how"), and knowledge (students know "what") (Education and Culture Ministry policy, No. 68 year 2013).

The 2013 curriculum emphasizes more on competences and character buildings, because characters have important values to run and form the ethical and individual principles (Howard et al., 2004). The students attain academic benchmarks to construct and employ their knowledge and skills and need the same time and opportunity to develop and conduct good characters (Stein et al., 2000).

The Ministry of Education (2013) states that the 2013 curriculum can be implemented successfully by using Scientific Approach. Scientific Approach is a new approach in English Language Teaching because the term "scientific" is more familiar with natural science, social science and management (Suharyadi, 2013, p.1). The learning process adopts the scientist stages in building the knowledge through the science methods and characteristics (see Alfred De Vito: 1989; Government's file: 2013; Barringer, et al., 2010; Abidin, 2014). Thus, it is a challenge for teachers to understand the stages and basic knowledge about Scientific Approach in 2013 curriculum to implement the English Language Teaching in the classrooms properly (Ayuni, 2015).

Scientific Approach does not only emphasize learning outcomes as the end result, but also the learning process as the important consideration.Therefore, this approach highlights the quest of knowledge rather than the knowledge itself. The students need to be actively involved in the learning process to present the information which is acquired not only from the teachers but also from various resources.

According to Regulation of Ministry of National Education No. 65, Scientific Approach in 2013 curriculum trains the students to: (1) be the center of learning, (2) involve the cognitive processes which is potential in stimulating intellectual development, specifically the high level of student; thinking skill, (3) give opportunities to the student to assimilate and accommodate concepts, laws and principles, (4) find knowledge through scientific process and use it in learning process, (5) learn from various sources, (6) promote acculturation and empowerment of students as lifelong learners, (7) apply values by giving exemplary things, build willingness, and develop creativity of the students in the learning process, (8) implement the principles in which everyone is teacher, everyone is student and everywhere is class.

Scientific Approach is paramount to improve the quality of teaching and learning. It directs the students to develop and integrate their attitudes, skills and knowledge (Suharyadi, 2013, p. 1). The approach can encourage students to be capable of observing, questioning, experimenting, associating, and communicating (Government's file, No. 103, 2014; Abidin, 2014, p.132; Hosnan, 2014, p. 37; Mulyasa, 2014; Suharyadi, 2013, p. 1350). Each of the steps is presented as follows:

1) Observing - to develop student's curiosity, to create meaningful learning process and help students acquire knowledge (Brown, 2000). The teacher asks the students to observe objects, events, phenomena, concepts and procedures by using all of their senses to see, listen, read and watch, and integrate it with the learning material (Checkovich \& Sterling, 2001, p. 32; Government's file, 2015). At the same time, students construct their knowledge and facilitate them to fulfill their need of knowing something. In this activity, the context is also presented to make students connect what they have learned with what they are going to learn (Suharyadi, 2013, 
p. 3). According to Kemendikbud (2013b), the observation is going to be effective if the teacher and students employ tape recorder (to record the conversation), camera (to record visual objects), film or video (to record audiovisual objects) and related equipment.

2) Questioning - to construct knowledge as a concept. The students are required to have a critical thinking to evoke high level of thinking questions. Furthermore, the students can show their active participation in the learning process. In this stage, the teachers have to facilitate the students with scaffolding to stimulate and encourage the students to ask

(Government's file, 2013, pp. 34-35). Questioning can be used by both teachers and students in the classroom with several specific purposes. Specifically, by giving questions, the teacher leads the students to give their attention to begin learning and stimulate them to pursue knowledge on their own (Suharyadi, 2013, p. 3-4).

3) Experimenting - to acquire a meaningful, real and authentic learning, students have to do experiments, especially to the suitable materials (Suharyadi, 2013, p. 4). The students also experience the skill process to enhance knowledge and employ scientific method to solve the real problem. Experimenting is intended to develop various learning objectives, attitudes, skills and knowledge. It is an activity to internalize knowledge and skills that have been learned. The students practice to express new things that they have learned and try to utilize the skills to reality inside and outside the class through simulation, role play, presentation, discussion and games (Government's file, 2013, p. 35).

4) Associating - toattain the conclusion of knowledge by a logical thinking process and systematic empirical factual statement which is observed. Students must be more active and given more opportunities to learn. Associating refers to grouping ability of various ideas and associating various events to be part of memory.
When the experiences are stored in the brain, they will interact with the previous events or experiences. In this stage, students and teacher are engaged into learning activities, such as text analyzing and categorizing. The information or data that have been collected from the previous activity (observing and experimenting) must be analyzed to draw conclusions. Students will then process the information from the teachers and draw the conclusions out of that information. As stated on the Policy of Indonesia Ministry of Education and Culture No. 81a/2013, associating process must be conducted through: (1) processing information that has been collected from the result of experimenting and observing activity and, (2) processing the information collected to find solutions from variety of sources that have different opinions to the contrary. Thus, students are expected to be able to relate the result of learning or experimenting to the reality.

5) Communicating - to develop students' skills to offer or demonstrate all knowledge and ability that has been mastered verbally or nonverbally. Suharyadi (2013, p. 4) argues that communicating is also called collaborative learning. For teachers, the collaborative learning function is more directive oriented in which the teachers are managers in the students' learning. The students present the communicative and effective written or spoken knowledge based on what they have learned.

The Scientific Approach has learning models to implement the whole approach, strategy, and method components which are employed holistically and comprehensively in learning process. The model selection is based on (1) time allocation; (2) material contents; and (3) asessment process of knowledge and skill (Hasanudin, 2017). The models include discovery learning, inquiry learning, problem based approach and project based approach.

In addition, in implementing the teaching practice in 2013 curriculum, lesson 
plan has an important role to guide the learning activities to achieve basic competences (Permendikbud no.65, 2013). In this research, some lesson plan components are analyzed. The components include indicators, objectives, learning material, learning activities, and assessment (Ministry of National Education, 2013)

Considering the issue stated above, this research is intended to focus on the implementation of Scientific Approach in English language teaching and its conformation with the lesson plans. It is hoped that this study can give a major contribution in the area of English teaching in new 2013 curriculum that is recently discussed nowadays, especially, Scientific Approach as a new approach in teaching English. It can help other researchers in conducting further researches on Scientific Approach.

\section{METHOD}

To meet the purposes of the study, the research employed a qualitative case study research design since the main objectives are to describe and analyze the English teachers' implementation of Scientific Approach and the conformation with the teaching lesson plan in 2013 curriculum.

The research was conducted in one of favorite junior high schools in Bandung Regency which has been popular and chosen to apply Scientific Approach for English learning and teaching since the 2013 curriculum was realized. The participants involved in this research were three eleventh grade teachers. They were free to choose the topic as long as it is stated in basic competence 3 and 4 in seventh grade level. They were trained on the 2013 curriculum by the government and one of them is a national instructor.

Since this study employed a case studyqualitative research design, the data were collected through classroom observation, teachers' lesson plans analysis and interview. The classroom observation was recorded and analyzed in the form of transcription and rubric. The observation began on March. Then, the lesson plans were analyzed to determine whether the lesson plan is in line with the principles of 2013 Curriculum. The teachers' lesson plans were analyzed in terms of the indicators, objectives, materials and media, teaching procedures (Scientific Stages and its model) and learning assessment components (Decree of Minister of National Education no. 65/2013). The lesson plans were collected from each teacher after conducting the observations. There were four lesson plans analyzed in this study. The first lesson plan labeled L1 was made by Teacher A; L2 and L3 was for lesson plans made by Teacher B; and L4 for lesson plan made by Teacher C. All lesson plans were written in Indonesian.

Finally, the interview was done to each teacher after finishing the classroom observations to gain detailed information and description about Scientific Approach in 2013 curriculum. The interview consists of six questions related to the implementation of Scientific Approach in 2013 curriculum and the data was categorized as complement to answer research questions. The interview was conducted in Indonesian to make the teachers more comfortable in expressing their opinions regarding the implementation of Scientific Approach.

\section{RESULTS AND DISCUSSION}

The section is divided into three main parts. The first part presents the implementation of Scientific Approach in English Language Teaching observation. The second part highlights the conformation between the implementation and the lesson plans through the lesson plans analysis. Finally, the interview supports the first and second findings.

\section{Data from classroom observation Observing}

In the teaching practice, teacher A conducted the same material (describing things) in two different classes. She used the monkey doll to be described in class A, and red ball and bottle in class B. She was creative in using the contextual, real and some relevant media. She presented different realia to be described. Thus, it made the students engage 
easily in the learning process because she asked the students to use their sense to see.

Teacher $B$ also presented the same material (describing people) for class $\mathrm{C}$ and $\mathrm{D}$. In observing, she asked the students to maximize their sense to see the idol picture to be portrayed. It led the students to have fun learning and involved them to create active and meaningful learning. On the other hand, teacher B in class E displayed different material (greeting). Here, the teacher invited the students to watch the video and sing the greeting song. So, the teacher asked the students to use their sense to watch and listen. In addition, teacher $C$ stated some verbal instructions to be listened and observed. Then, she asked the students to note the instructions given.

According to the findings, all teachers implemented the observing stage well. It emphasized that all the teachers were creative to utilize the relevant, contextual and real media to be observed.

\section{Questioning}

In this stage, teacher A involved the students to make questions verbally and invited some representatives to write the questions in front of the class. Uniquely, she kept stimulating the students to answer and create more questions. The teacher applied active learning to bring good atmosphere. She explained (1) the usage of "has/have" and "is/are", and (2) constructed the statements and questions to describe the thing clearly. Thus, it made the students create the questions and statements easily. Teacher B and $\mathrm{C}$, on the contrary, kept asking the related questions and conduct the group discussion to encourage the students to ask and give their arguments.

In this stage, all teachers showed their effort to encourage, stimulate and motivate the students to offer and response the related questions. They tried to construct the active learning and develop the students' thinking skill. Practically, the goals were not achieved well. So, the teachers initiated to offer some related questions and make a discussion to encourage the students to offer questions, respond to the answers, and give the argumentation and opinion.

\section{Experimenting}

In experimenting, the students get real or authentic learning (Abidin, 2014). Teacher A gave the opportunity to the students to explore and collect relevant data and practice the writing and pronunciation to describe things. Teacher B asked the students to collect the data from the internet and practice to describe people' appearance and personality. In addition, in teaching the other material (greeting), the teacher asked the students to practice and imitate the greeting expression. Finally, teacher $\mathrm{C}$ guided the students to explore and find the instruction from the text book. She also asked them to modify, imitate and demonstrate the instruction.

\section{Associating}

Associating refers to the ability of creating diverse idea and making new concepts or relating the result of learning experimenting to the reality they find (Ministry of Education and Culture No. 81a/2013). Teacher A and B encouraged the students to analyze and modify the descriptive statements. Then, the students associated their knowledge from observing and experimenting to describe things (Teacher A) and people (Teacher B). In addition, teacher B instructed the students to modify and create greeting songs. Further, the teacher $\mathrm{C}$ asked the students to analyze and make instruction.

\section{Communicating}

In communicating, teacher A asked the students to describe one of the things given by using be, have and has in the groups of two. Then, she watched and gave them assessment. Teacher B built collaborative and cooperative learning in groups of four. The students were asked to choose one idol picture or the family member, then they discussed it in the groups. The representatives of the groups presented the description while the teacher monitored and led their discussion activity. To conduct effective learning, it will be better if the implementation was conducted twice or three times to give time for the students to explore, 
associate and communicate well. Moreover, in teaching greeting, the teacher asked the students to sing with their groups in front of the class. In addition, teacher $\mathrm{C}$ asked the students to come forward and communicate the instruction alternately in pair.

\section{Document analysis}

This section presents the analysis of lesson plans. There are four lesson plan samples investigated in the study.

\section{Learning indicators, learning objectives and learning materials}

Deciding indicator refers to the basic competence. Indicators direct to develop learning material to achieve learning objectives. The indicators are explained by detailed objectives. Teacher A and B conducted the basic competence 3.10 and 4.13. Both teachers fulfilled the indicators by using $\mathrm{C} 2$ and $\mathrm{P} 2$ in line with basic competence and their learning objectives followed the $\mathrm{ABCD}$ rule. On the other hand, in deciding learning material, teacher A chose the things to be described and used realia by using various things such as monkey doll, red ball, red bottle and others while teacher B selected admired people to be described and employed pictures as the media.

Teacher $\mathrm{B}$, in the third teaching, presented KD 3.1 and 4.1. KD 3.1 had three indicators. The operational words come from same level of Bloom's taxonomy (C2). She did not put the learning objectives in the lesson plan. In addition, KD 4.1 has one indicator and no learning objective. The word "menciptakan" in indicators must be followed by the lowest operational word to scaffold the students. Furthermore, the teacher utilized video and song as learning media to teach greeting expression.

Teacher C selected KD 3.9 and 4.10. KD 3.9 has three indicators, the indicators are not in line with one learning objective mentioned in this lesson plan. This also happened to KD 4.10 where the teacher put one indicator and two learning objectives. As Dede (2017) stated that in the lesson plan of 2013, the number of indicators has to be in line with learning objectives. The learning objective almost follows the ABCD instruction. However, the teacher did not mention the bond degree of KI 2 such as "dengan benar dan tepat". The teacher conducted instruction for the learning material, the students are asked to identify the language features of instruction (Verb + Object!). Thus, the learning material and basic competence are relevant. Furthermore, the teacher was creative because she used realia, situation and condition as the media of learning, for instance the teacher pointed the door and say "Arya, open the door, please!" or "let's learn about the instruction, now open page 101!”

\section{Analyzing scientific approach and learning model}

In this section, the lesson plans were analyzed in term of its syntax to discover learning model that the teachers chose in their teaching practice. Scientific Approach includes some learning models such as Discovery Learning Method, Project-Based Method and Problem-Based Method. Those models have different syntax depends on the characteristics of the models. The teachers' teaching practices were then analyzed to discover their learning models.

The detail elaboration of learning model in the four lesson plans of the teachers is discussed in the following subsections.

\section{L1 Teacher A and L2 Teacher B}

Both lesson plans present scientific stages and discovery model of learning in the sequence activities. First, the activities construct the active learning and reflects the student-centered process. The proof can be seen from the beginning of the lesson when the teacher asks the students to observe the monkey doll (Teacher A) and the idol picture (Teacher B) as the observation stage in Scientific Approach and stimulation in discovery model. This activity leads the students to use their sense to see and engages them to the learning. 
The second finding, the questioning stage is conducted well by giving the students several questions related to the material and discussion to encourage them to argue, question and response. The question stage is in line with problem identification in discovery learning.

The third, experimenting is line with collecting data. Here, the teachers give chance to the students to explore more information from various resources such as accessing the internet or discussing with their groups to collect more information and material to describe the things and initiate the pronunciations.

The fourth, the associating stage or verification in discovery learning displays the teacher asking the students to analyze and elaborate their current knowledge to describe the new things (teacher A) and idol (teacher B).

Finally, in communicating and generalizing stage, the students are instructed to make short description of the thing given, then they present their description in form of dialogues in pairs (teacher A), while teacher B asked the students to present their admired people description in the groups of four and the representatives came forward to describe it in front of their friends.

In the lesson plan, the teacher implements scaffolding which means the task that students have to do is in the sequence activities from the easiest to the hardest. This stage makes the students get the meaningful learning whereas each individual will fully understand the learning materials.

\section{L3 Teacher B and L4 Teacher C}

Both teachers do not mention the model. They only focus on the scientific process stages. However, in 2013 curriculum activities the Scientific Approach stages must be in line with the learning model (Government's file, 2015).

The L3 of Teacher B conducts observing stages using video and song to engage the students, then both teacher and students discuss the song's content. It is hoped that this stage can encourage the students to ask. Meanwhile, teacher $\mathrm{C}$ employs verbal expressions to be listened by the students, then she stimulates the students to offer questions.

In experimenting, teacher B instructs the students to collect data from videos, songs and other resources. Then, they classify formal and informal greeting expressions. Further, they imitate teacher's pronunciation in expressing the words. On the other hand, teacher $\mathrm{C}$ uses text book to be explored. She asks the students to obtain the instruction and identify its language features.

In associating, teacher B instructs the students to analyze the expressions and create simple song based on the data gained and sing in front of the class in form of group. In addition, teacher $\mathrm{C}$ displays the students to modify the instruction and presents the simple dialog in pair.

\section{Analyzing learning assessment}

In 2013 curriculum (2015 version), spiritual and attitude aspectsare explained in line with cognitive and skill assessments. However, in 2017 revision, the English teachers just assess the students' cognitive and skill, while attitude is assessed implicitly. Spiritual and attitude aspects are assessed by religion and civic subjects (Hasanudin, 2017). Based on the finding, all teachers assess the students' cognitive and skill by employing the verbal test assessment.

\section{Data from interview}

The interview as the follow up to the observation was conducted with the English teachers of 7th grade. The Scientific Approach has been implemented since the school started employing the 2013 curriculum and chose to be a model school. The Scientific Approach asks the teacher to learn and read a lot. They are able to understand the stages by sharing with friends, reading from various information and following the national or local training of the 2013 curriculum. In addition, they always design the lesson plan before conducting the teaching. 


\section{CONCLUSION}

The present study shows that the English teachers of 7 th grade at the chosen state junior high school implemented the Scientific Approach in their English Language Teaching. They conducted all the stages involving observing, questioning, experimenting, associating and communicating. To emphasize, the teachers need to consider the time for implementation because the students need much opportunities to dig the stages.

Furthermore, the teachers conducted active and meaningful learning but they still lack of critical thinking (HOTS). Observing was conducted with various media and creative delivery. However, they have to highlight the questioning stages where the students did not initiate to learn without stimulation and encouragement from the teachers. Thus, it made the teachers show their efforts to stimulate and motivate them to offer questions. Besides, the teachers employed the discussion to make them creating the active, cooperative and collaborative learning.

In addition, the lesson plans employ all components and Scientific Approach stages based on 2013 curriculum. However, the teachers need to emphasize the step of determining the learning indicators and learning objectives, stating the learning model, and choosing the method. The findings show that teacher A and teacher B (Class B and C) implemented the teaching in line with their lesson plans while teacher B (class D) and C were less appropriate because they did not write the learning objectives and model. As Mikova (2017) states that learning objectives, learning activities and learning assessment are the main points of lesson plan.

\section{REFERENCES}

Abidin, Y. (2014). Desain sistem pembelajaran dalam konteks kurikulu 2013. Bandung: PT Refika Aditama.

Alwasilah, A. C. (2012). Pokoknya kualitatif: Dasardasar merancang dan melakukan penelitian kualitatif $\left(7^{\text {th }} E d\right)$. Bandung: PT. Dunia Pustaka Jaya.

Hosnan, M. (2014). Pendekatan saintifik dan kontekstual dalam pembelajaran abad 21: Kunci sukses implementasi kurikulum 2013. Bogor: Ghalia Indonesia.

Mulyasa, E. (2014). Pengembangan implementasi kurikulum. Bandung: Penerbit PT. Remaja Rosdakarya.

Suharyadi. (2013). Exploring scientific approach in English language teaching. Malang: The State of Malang University.

Yani, A. (2014). Mindset kurikulum 2013. Bandung: Alfabeta. 